\title{
What is the impact of the Rashomon approach in primary care education?: An educational case report of implementing dialogue and improvisation into medical education
}

\author{
Akiteru Takamura ${ }^{1 *}$ (1) and Rintaro Imafuku² ${ }^{2}$
}

\begin{abstract}
Background: The excessive sub-divided or concrete pre-determined objectives found in the technological approach in contemporary medical education curricula may hinder the students' spontaneous learning about diverse needs and values in care. However, medical professionals must learn the diversity for care or a variety of social factors of the patients influencing decision making in daily practice.

Methods: We introduced a new method of curriculum development called the Rashomon approach. For testing the Rashomon approach, educational activities to teach the diversity in primary care were developed in four modules: 1) explication of the competency without specifying sub-objectives; 2) dialogue among multiple professional students; 3) visits and interviews of the patients; 4) dialogue with teachers' improvisation. The students' outcomes and responses were quantitatively and qualitatively analyzed.

Results: A total of 135 medical students joined this study in 2017. The descriptive data suggested that the key concepts of diversity in primary care were fully recognized and that the pre-determined general goals were achieved. Scores on the understanding of social factors in medicine, respect for other professionals, professional identity, and satisfaction with the course were very high.

Conclusion: Instead of the technological approach, the Rashomon approach, in which only a general goal guides educational activities was used in this research. Improvisation and dialogue fit the approach and were potentially effective activities to learn the multifaceted practice of medicine. In an era of competency-based education, the Rashomon approach could be a very useful framework in primary care education.
\end{abstract}

\footnotetext{
* Correspondence: akiteru@kanazawa-med.ac.jp

'Department of Medical Education, Kanazawa Medical University, 1-1

Uchinada-machi Daigaku, Kahoku-gun, Kanazawa, Ishikawa 920-0293, Japan

Full list of author information is available at the end of the article
}

(c) The Author(s). 2021 Open Access This article is licensed under a Creative Commons Attribution 4.0 International License, which permits use, sharing, adaptation, distribution and reproduction in any medium or format, as long as you give appropriate credit to the original author(s) and the source, provide a link to the Creative Commons licence, and indicate if changes were made. The images or other third party material in this article are included in the article's Creative Commons licence, unless indicated otherwise in a credit line to the material. If material is not included in the article's Creative Commons licence and your intended use is not permitted by statutory regulation or exceeds the permitted use, you will need to obtain permission directly from the copyright holder. To view a copy of this licence, visit http://creativecommons.org/licenses/by/4.0/ The Creative Commons Public Domain Dedication waiver (http://creativecommons.org/publicdomain/zero/1.0/) applies to the data made available in this article, unless otherwise stated in a credit line to the data. 


\section{Background}

Competency-based medical education (CBME) has become a core pedagogical paradigm to ensure that the graduates have developed the competencies required to be responsive to the needs of the communities they will serve [1-3]. Competency-based frameworks for medical education define competencies to be achieved, promoting transparency in education $[4,5]$. This allows training organizations to confirm whether an educational program successfully produces graduates with the competencies needed for practice $[6,7]$.

However, there are also concerns in the implementation of CBME. The definition of CBME is subject to inconsistency because the term "competency" describes a rather broad concept. As the competencies, even though including broad abilities, must be incorporated CBME into their curricula, teachers must break down a competency into a number of objectives with concrete, specific and behavioral expressions; this is called the technological approach [8]. In this approach, the learning strategies and materials are systematically planned in accordance with the targeted objectives. Assessments for the objectives also need to be set according to detailed objectives [9-11]. While long lists of learning objectives across the curriculum can guide students' learning, it becomes difficult to support individual learning needs through flexible learning plans [3]. The technological approach may not allow teachers to fully capitalize on the comprehensive nature of CBME or to encourage learners' flexible thinking and diverse values.

The field of social medicine seeks to provide social care by understanding how social and economic conditions affect health and illness, and foster the conditions that lead to a healthier society [12]. The social determinants of health $(\mathrm{SDOH})$, to which increased attention is now being paid in medical education, are a complex array of political, economic, environmental, and cultural factors that strongly influence health status and equity [12-14]. This means that modern healthcare providers need to understand that the care is not universal for all patients. Incorporating information on the $\mathrm{SDOH}$ into health professions curricula is challenging for teachers because the content of SDOH differs among the individuals or communities [15]. Developing effective ways of teaching variable knowledge that can adapt to the change is needed [16, 17].

Previous studies have emphasized the importance of diversity in teaching medicine, particularly in the field of primary care [18]. Physicians must respect the diversity of patient values and societal needs. Even in cases of an established diagnosis, patient care varies depending on the SDOH surrounding the patient [19]. Healthcare providers must have a high degree of competency to comprehensively understand and solve problems for each patient. As such, we must consider ways to teach the multidimensional themes of diversity and individuality in medicine. This is a limitation of the present technological approach in CBME.

There is a need to develop a new pedagogical approach to teaching the multifaceted, multi-valued themes of diversity in medicine in society. Therefore, we developed an educational program of social medicine that employs the Rashomon approach, which stresses the importance of learner subjectivity and of inductively assessing student learning through observing interactions among students, teachers, and educational resources. This study aimed to investigate how the Rashomon approach shapes medical students' education on diversity in medicine.

\section{The Rashomon approach}

The Rashomon approach was named after the 1950 film, Rashomon. In this film, a single event, a homicide is described from the different perspectives of the characters. In the Rashomon approach, teachers, like film directors, need to fully understand the big pictures so that they can engage characters = students in creative learning activities which relates to the general goals. Having a deep understanding of goals allows teachers to offer the learning activities based on their own experience and technical expertise, which is a key tenet in the Rashomon approach. In the film, flashbacks and flash-forwards were used extensively and this technique can be used to reinforce information and to stress different aspects as required $[20,21]$. In the Rashomon approach, it is expected that diverse learning can be facilitated when teachers add different ideas and improvised activities to learning based on their experiences. The Rashomon approach also functions as an evaluation method for various learning of students from the activities and comprehensively assessing learners' understanding. It is important in terms of the educational impact that unintended achievements are also emphasized in the Rashomon approach [22, 23] Therefore, in this approach, teachers must have the ability to create activities that are appropriate for the learning situation and to comprehensively assess learners. Atkin clarified the differences between the Rashomon approach and the technological approach. (see Table 1) [24-26]. In the technological approach, educational content is organized based on the teacher's intentional educational plan. A general educational goal (Competency), which is defined as a comprehensive expression of the goals to be educated, is set first and then classified into sub-goals, which are further divided into specific objectives. To achieve these goals, teachers must plan, select and employ appropriate teaching strategies. In the technological approach, assessment requires objectivity, relevance, and credibility, making it 
Table 1 The difference between Technological approach and Rashomon approach

\begin{tabular}{|c|c|c|}
\hline & Technological approach & Rashomon approach \\
\hline Developing Process & $\begin{array}{l}\text { Competency } \\
\text { (General Educational Goals) } \\
\downarrow \\
\text { Specific or Behavioral Objectives } \\
\downarrow \\
\text { Developing Learning materials } \\
\downarrow \\
\text { Implementing Learning Activities } \\
\downarrow \\
\text { Assessment with Objectives } \\
\downarrow \\
\text { Assessment with Competencies }\end{array}$ & $\begin{array}{l}\text { Competency } \\
\text { (General Educational Goals) } \\
\downarrow \\
\text { Creative Teaching and Learning Activities } \\
\downarrow \\
\text { Record or Description } \\
\downarrow \\
\text { Assessment with Competencies }\end{array}$ \\
\hline Objectives & Specific, Behavioral & $\begin{array}{l}\text { General and non-Behavioral } \\
\text { Or } \\
\text { Unset }\end{array}$ \\
\hline Learning Materials & Planned and Targeted & Discover in Learning Process \\
\hline Learning Strategies & Planned and Targeted & Improvisation \\
\hline
\end{tabular}

necessary to define a generalized concept as well as certain criteria for the course evaluation.

Like the technological approach, the Rashomon approach begins with setting general goals. However, without classifying these into specific sub-goals or small objectives, teachers then generate a variety of creative teaching and learning activities on general goals, making use of their experience as experts. All events triggered by these learning activities - not only those related to the originally set general goals-should be observed and recorded [27]. In this approach, multifaceted observations of all events are incorporated into the evaluation. The effects are fed back through creative teaching and learning activities which can be achieved in an infinite number of ways.

In this respect, Rashomon's approach is unique because it encompasses both aspects of learnercentered and teacher-led education [28]. In addition, in this approach, students learn an educational goal that includes unplanned insight from a variety of perspectives through creative learning activities with teachers.

\section{Methods \\ Outline of educational curriculum using Rashomon approach (see Table 2) \\ Setting}

Medical schools in Japan are six-year undergraduate programs. In the 2016 revision of the core curriculum for medical schools in Japan, the Ministry of Education, Culture, Sports, Science and Technology (MEXT) emphasized the importance of social medicine in medical education [29]. Traditionally, Kanazawa Medical University has offered classes in third-year medical students on diversity in medicine with a didactic approach, in a series of lectures. However, from the feedback from students after the classes, it could not be said that it was not sufficiently learned. We developed a new curriculum and Third-year medical students at Kanazawa Medical University joined the learning session.

\section{Learning strategy \\ Interprofessional patient home visits and dialogue}

We developed a social medicine program consisting of four modules. We offered an improvisation activity to

Table 2 Outline of Social Medicine Learning based on Rashomon Approach

\begin{tabular}{|c|c|}
\hline Rashomon approach & Social Medicine Learning Session \\
\hline $\begin{array}{l}\text { General Educational Goals } \\
(\fallingdotseq \text { Overall Competency) }\end{array}$ & $\begin{array}{l}\text { "Understand the relationship between society and health / diseases and learn the impact on health } \\
\text { of individuals and social life due to changes in environmental factors surrounding individuals and } \\
\text { group of people." }\end{array}$ \\
\hline $\begin{array}{l}\text { - Creative Teaching and Learning Activities } \\
\text { "Discover the value of learning material in } \\
\text { learning process" } \\
\text { "Emphasis on improvisation" } \\
\text { - Record or Description of Learning }\end{array}$ & $\begin{array}{l}\text { - Developing teaching and learning activities based on creative task interpretation } \\
\text { - Module 1: Explication of the overall competencies } \\
\text { - Module 2: Dialogue among students } \\
\text { - Module 3: Visits a patient's home and interviews } \\
\text { - Module 4: Dialogue with teachers' improvisation } \\
\text { - Faculty's Competencies } \\
\text { - As unexpected lesson could be developed, it might be fun but tense for faculty. } \\
\text { - It emphasizes the competence of the faculty as professionals. }\end{array}$ \\
\hline - Assessment with Competencies & $\begin{array}{l}\text { - Assessing the descriptive data (written data) from the students (What they learnt and what } \\
\text { they understand) }\end{array}$ \\
\hline
\end{tabular}


facilitate peer-to-peer and teacher-to-student dialogue from multifaceted viewpoints. The students were divided into groups comprising medical students, nursing students, and pharmaceutical sciences students. The first module was an interactive lecture-based four-hour introduction class to clarify the general goals suggested by MEXT. These general goals were as follows: Understand the relationship between society and health/diseases and Learn the impact of changes in environmental factors surrounding individuals and groups of people on their health and social lives [29]. The students were asked to investigate the issues for the general goals and identify factors influencing patients' social lives and health. The second module was an interactive team-based four-hour dialogue session. Each group decided in detail what information to collect from the patient based on the general goals suggested by MEXT. As the group members were from different professional fields, they were able to come up with ideas from their own field's point of view. The third module consisted of patient's home visits over a three-day period. Students visited the patients' homes and attempted to pursue the key inquiries discussed in Modules 1 and 2 through conversation with the patient. In the fourth module, there was another dialogue session with the students and three teachers who are a doctor, a nurse, and a pharmacist, have over 10 years' clinical experience in communities. During this session, the students presented their experiences at the patient's home. The teachers added impromptu explanations to go along with the students' answers and participated in the dialogue with the students. They asked relevant questions, and shared their ideas and experiences to help the students deepen their understanding of the gathered information. Because these improvised responses based on the teachers' clinical experience were intended solely to facilitate the learners' understanding, the teachers never sought predetermined answers to their questions or led the discussion in a way that students would find particular solutions to the problems they presented during the session.

\section{Data collection}

To clarify how and what students learned through the sessions based on the Rashomon approach, we developed a feedback survey to assess the utility of the curriculum and to determine which concepts the students perceived as most beneficial after completing the four modules [30, 31]. A questionnaire and a survey were designed to understand the strengths and the weakness of the curriculum. The questionnaire consisted of five questions that asked about the content of this curriculum. The questions were about students' understanding of the general goals and their usefulness in practice, the importance of respecting other professions, the establishment of self-identity, and the enjoyment of the session itself (Additional file 1). Medical students ranked their responses on a five-point Likert scale as follows: $1=$ worst, $2=$ not good, $3=$ neutral (neither not good nor good), $4=$ good, $5=$ best. The survey consisted of two semi-structured questions that specifically asked what students had learned through the session and what the structure of the session had been. These were written as free statements (Additional file 2). To preserve anonymity, identifying information was not requested.

\section{Data analysis}

For the quantitative data analysis, we used descriptive statistics to analyze the students' responses to the questionnaire about the learning modules. Statistical analyses were performed using IBM SPSS Statistics for Windows, Version 20 (IBM Corp., Armonk, NY, USA). For the qualitative data analysis, all survey answers were reviewed to identify keywords and concepts for coding. From this, we created an initial thematic map. Using the thematic analysis method, we then defined and named the final themes for analysis to develop a final thematic map [32]. To validate the constructs, preliminary results were shared with other members of the teaching staff in the same department who were not otherwise involved in the analysis. This study was approved by the Kanazawa Medical University Review Board. IRB number is I-090.

\section{Results}

\section{Student evaluation scores reported in the questionnaire (see Table 3)}

A total of 135 medical students who completed this course responded to the survey. Their scores of the modules' usefulness were very high overall. The students' mean (SD) usefulness evaluation scores were 4.4 (0.4) for understanding social determinants of health, 4.4 (0.57) for future practice, 4.5 (0.54) for respecting other professionals, $4.5(0.50)$ for their own self-identity as a doctor, and $4.3(0.45)$ enjoyableness.

\section{Student learning themes (see Table 4)}

Five themes were extracted from the students' descriptive data: 1) Comprehensive background of patients; 2) Multiple points of view from different types of a health professional; 3) Shared decision making with patients; 4) Many uncertain factors in medicine; and 5) Different patients' attitudes at patients' own places.

\section{Themes about the curriculum development with Rashomon approach (see Table 5)}

Similarly, an additional five themes were extracted from student descriptive data that seemed to be not directly related to educational goals but were considered important for curriculum development: 1) The importance of 
Table 3 The results of student evaluation scores of the course. On a scale of 1-5 with 5 being "very much"

\begin{tabular}{|c|c|c|c|c|c|c|}
\hline Question / Scale & 1 & 2 & 3 & 4 & 5 & Average Score \\
\hline Understanding social determinants of health, $n$ & 0 & 0 & 0 & 82 & 53 & $4.4 \pm 0.49$ \\
\hline Usefulness for future practice, $n$ & 0 & 2 & 0 & 76 & 57 & $4.4 \pm 0.57$ \\
\hline Respecting other professionals, $\mathrm{n}$ & 0 & 1 & 0 & 70 & 64 & $4.5 \pm 0.54$ \\
\hline Increasing Self-identity as a doctor, $\mathrm{n}$ & 0 & 0 & 0 & 67 & 68 & $4.5 \pm 0.50$ \\
\hline Enjoyable, $\mathrm{n}$ & 0 & 3 & 2 & 60 & 70 & $4.3 \pm 0.45$ \\
\hline
\end{tabular}

and interest in self-directed learning; 2) A framework for information provided to students based on teachers' experience; 3) Different perspectives and values among health professionals; 4) Having fun engaging in dialogue and naturally understanding topics; and 5) Anxiety regarding assessment.

\section{Discussion}

This study has investigated how the Rashomon approach shapes medical students' learning of the $\mathrm{SDOH}$ in

Table 4 Theme of the students' learning and students' comments

\begin{tabular}{|c|c|}
\hline \multicolumn{2}{|c|}{$\begin{array}{l}\text { What have you learned in this social medicine curriculum? } \\
\text { How was the learning session with the lecturer? }\end{array}$} \\
\hline Theme & $\begin{array}{l}\text { Example of Medical Students' } \\
\text { Comment }\end{array}$ \\
\hline $\begin{array}{l}\text { Comprehensive background } \\
\text { of patients }\end{array}$ & $\begin{array}{l}\text { Student A "As a result of having a good } \\
\text { relationship with sufficient preparation in } \\
\text { advance and enough time at the } \\
\text { patient's home, I was able to hear about } \\
\text { the patient's life and thoughts." }\end{array}$ \\
\hline $\begin{array}{l}\text { Multi health professionals' } \\
\text { points of view }\end{array}$ & $\begin{array}{l}\text { Student B "I have been able to know the } \\
\text { patient from various aspects because I } \\
\text { got many viewpoints from other } \\
\text { professional students that I do not } \\
\text { notice, such as the medicine and the } \\
\text { things that the patients should be aware } \\
\text { of in their daily life." }\end{array}$ \\
\hline $\begin{array}{l}\text { Shared decision making with } \\
\text { patients }\end{array}$ & $\begin{array}{l}\text { Student C "The patient had a strong will } \\
\text { for future life-prolonging treatment. Since } \\
\text { it was completely different from my } \\
\text { thoughts, different people had different } \\
\text { values and I felt that I had to discuss and } \\
\text { decide." }\end{array}$ \\
\hline $\begin{array}{l}\text { Many uncertain factors of } \\
\text { medicine }\end{array}$ & $\begin{array}{l}\text { Student D "I have studied biologically } \\
\text { clinical reasoning, diagnosis, and } \\
\text { treatment in the class, but I understood } \\
\text { that when it comes to real practice, I } \\
\text { have to consider not only the patient's } \\
\text { values but also the economic and family } \\
\text { conditions." }\end{array}$ \\
\hline $\begin{array}{l}\text { Different patients' attitudes } \\
\text { at patients' own places }\end{array}$ & $\begin{array}{l}\text { Student E "I noticed a difference in the } \\
\text { facial expression of the patient at home } \\
\text { compared to the university hospital. I } \\
\text { thought it was important to check the } \\
\text { various situations at home because there } \\
\text { were a lot of things I didn't know in the } \\
\text { consultation room at the hospital as to } \\
\text { what kind of life the patients have and } \\
\text { how they have a relationship with my } \\
\text { family." }\end{array}$ \\
\hline
\end{tabular}

primary care settings [33, 34]. At the beginning of the program, we presented general goals for learning to students. These goals offered just a framework for the students to better understand patient diversity. However, we intentionally did not set specific objectives ahead of time. This approach allowed us to support studentcentered active learning. The absence of specific objectives was particularly important in the planning stage, when students' groups discussed and identified the information that should be elicited from the patients.

Student groups visited patients' homes rather see the patients at the university hospital. This created an environment where patients could more openly share their opinions with the students. Moreover, our findings show that this approach allowed students to gain

Table 5 Theme about the curriculum development with Rashomon Approach from the students' comments

\begin{tabular}{ll}
\hline Other Important Themes on Learning \\
\hline Theme & Example of Medical Students' \\
& Comment \\
\hline The importance of and interest & Student F "We have learned what \\
in self-directed learning & teachers teach in class, but when \\
& there are a lot of factors we have to \\
& take into account, there are limits to \\
& teaching, and I felt it was important \\
& to learn in people who have a variety \\
of values."
\end{tabular}

A framework for student information provided by the lecturers' experience

Student G "The teacher's experiences helped me to understand, but the teacher's values also have a big impact on students."

Different perspectives and values among health professionals

Student H "It was easy for me to understand that we had different views from pharmacy students and nursing students, but I was surprised that the view was very different even among the medical students. I realized that doctors may have their own way of thinking about treatment policy."

Fun of dialogue and naturally understanding topics

Student I "Everyone had a natural and enjoyable understanding through the dialogue on a large theme rather than just learn what was decided."

Anxiety regarding assessment Student J "I am worried about how my assessment will be done because there are no clear learning objectives and no criteria for the assessment." 
multidimensional real-world experience in primary care they would engage in as doctors. Indeed, three themes (comprehensive backgrounds of patients, different patients' attitudes and patients' own places, and shared decision making with patients) indicated that the students experienced the real lives of patients who might have found it easier to share their stories outside the hospital context during the patient home visits.

The spread of evidence-based medicine has advanced the standardization of disease treatment policies. On the other hand, health professionals often play a role in solving patient social and psychological problems that include complex, multifaceted issues. Although teaching uncertainty and diversity in care is challenging, the students perceived that they had learned about the many uncertain factors in medicine through the modules. The results suggest that the students were able to understand the various perspectives of the patients and different health professionals.

In the field of medical education, assessing students' achievement of comprehensive competency in programs with competency-based curricula has become a significant challenge [3]. The broad nature of competencies complicates the assessment of students' achievements. As a result of fragmenting general competencies into numerous sub-goals, the competencies learners are actually able to acquire may be limited to those that were explicitly taught. To overcome this problem, our newly developed curriculum uses the Rashomon approach to provide a useful framework for assessing students' achievements from diverse perspectives [24, 35-37]. A better understanding of social medicine was set as a general goal, but the additional objectives that students achieved were not detailed in advance in this program. We think that this resulted in the broader achievement of the competency.

In accordance with the Rashomon approach, students were encouraged to engage in a deep dialogue amongst themselves concerning many elements of society based on their experience visiting a patient's home with their interprofessional student groups. In a dialogue, two individuals work with and challenge each other to collaboratively alter and deepen their understanding [38, 39]. Additionally, Bohm et al. stated that "no firm rules can be laid down for conducting a dialogue because its essence is learning" [40]. For this dialogue, teachers did not provide any instructions or learning strategies. Following the students' home visits, there was also a dialogue session between teachers and students. In the student-teacher dialogue, the faculty responded extemporaneously to student achievements and questions and refrained from evaluation through ranking, assigning scores, or completing checklists. This reflects the nature of dialogue and of the Rashomon approach [41].
However, it was still necessary to verify how much students deepened their understanding of the $\mathrm{SDOH}$ through this learning approach. Table 4 shows that students autonomously understood medical uncertainties and diversities, such as patient values, views on life, and other SDOH. Students described economic factors, cultural factors, the social environment, and even the importance of social networks. As mentioned above, it was likely easier for the patients to talk to the students about their social backgrounds in their own homes, reducing the cognitive load of this task [42]. It also may have been easier for the students to understand the contextual information gained by visiting the patients' homes through situated learning [43]. Using the information provided by the patients about polypharmacy and multimorbidity, the students came to understand the importance of shared care responsibilities and coordination between health professionals. In terms of patients' values, the students mentioned the importance of sharing their opinions and engaging in the decision-making process as a team including patients. Through dialogue with the patients in their places and through dialogue with faculty members in the classroom context, the students came to understand uncertainty and diversity in care, which can be seen as practicing social constructivism [44].

The results indicated that the newly developed curriculum using the Rashomon approach had a positive impact on the students' learning. Based on students' comments on some of the educational aspects of the Rashomon approach, they were able to understand the role of social factors and diversity in medicine. In particular, the dialogues provided a framework for the students' free and multi-valued learning. Teaching clinical problems with specific solutions in medicine is important, but it is also essential for students to develop the competency to manage problems with uncertain answers in daily practice.

Overall, the interprofessional students' learning with the Rashomon approach seems useful for students. Though in modern medical education, it is common to develop curricula with clear and measurable achievement goals, things which thought to be important but unwritten in the goals are often tend to be ignored. Clinical facts that the students should learn in the real world involves a variety of uncertainties and multiple aspects. This approach may be able to solve those issues. Activities involving teachers' improvisation encourages students to actively participate in learning and to gain a better understanding of diversity in medicine. Learnercentered education is important, but teacher-led education is also key in the Rashomon approach. SDOH education following the Rashomon approach provides an opportunity for students to learn how to effectively assess and address the social factors and difficulties that 
commonly accompany patients' biomedical concerns. It is important to set up a learning environment that presents a comprehensive set of general goals without subdividing objectives like the technological approach and that freely considers diverse values. Although the Rashomon approach appears to be generally effective, the areas in which the Rashomon approach is more effective for students' learning and the areas in which the technological approach is more effective remain unclear. In this case, we set the condition that students of various professional backgrounds participated and that part of the program was implemented at patients' homes. In addition, the improvisational skills of the teachers and the dialogues among students and with teachers played an important role in the sessions. While these conditions may have contributed significantly to the positive results in this study, the general conditions in which the Rashomon approach is more effective have not been established. However, there seem to be some limitations. Though we assessed the students' competency of understanding the diversity and the uncertainty in medicine by use of the questionnaire and the free-writing documents, this may not reflex their true achievement. To validate this approach, we need to measure the change of the students' behavior and performance in the future. In addition, the role of teachers is the most important key in this approach, and the achievement level of students may be influenced by the experience and values of teachers who lead the improvisational dialogue. Therefore, teacher training remains a challenge. And additional research is needed to determine under what conditions and in what domains to adopt the Rashomon approach.

This study demonstrates that students benefit from improvisation activities led by teachers and from dialogue among students and teachers in a program whose curriculum underpinned by the Rashomon approach. The Rashomon approach specifically focuses on facilitating students' understanding of diversity through creative learning activities. For learning variable factors such as $\mathrm{SDOH}$, curriculum development using the Rashomon approach seems to work, especially in primary care education.

\footnotetext{
Abbreviations

CBME: Competency-based medical education; $\mathrm{SDOH}$ : social determinants of health; MEXT: the Ministry of Education, Culture, Sports, Science and Technology in Japan
}

\section{Supplementary Information}

The online version contains supplementary material available at https://doi. org/10.1186/s12909-021-02570-6.

Additional file 1. The questions in the survey questionnaire.

Additional file 2. Social medicine survey questions.

\section{Acknowledgements}

The authors are grateful to all the study participants without whose collaboration it was not possible to conduct the study.

\section{Authors' contributions}

AT made substantial contributions to the conception and design of the work. AT and RI made the analysis and interpretation of data; and have drafted the work collectively. The author(s) read and approved the final manuscript.

\section{Funding}

None.

\section{Availability of data and materials}

The datasets used and analysed during the current study are available from the corresponding author on reasonable request.

\section{Declarations}

Ethics approval and consent to participate

This study was approved by the Kanazawa Medical University Review Board. IRB number is I-090. The participants filled out and signed a consent form for participating in the study, and permitting publication of the relevant data in the form of an article.

\section{Consent for publication}

Not Applicable.

\section{Competing interests}

The authors declare that they have no competing interests.

\section{Author details}

${ }^{1}$ Department of Medical Education, Kanazawa Medical University, 1-1 Uchinada-machi Daigaku, Kahoku-gun, Kanazawa, Ishikawa 920-0293, Japan.

${ }^{2}$ Medical Education Development Center, Gifu University, Gifu, Japan.

Received: 12 August 2020 Accepted: 19 February 2021

Published online: 04 March 2021

\section{References}

1. Carraccio C, Wolfsthal SD, Englander R, Ferentz K, Martin C. Shifting paradigms: from Flexner to competencies. Acad Med. 2002;5:361-7. https:// doi.org/10.1097/00001888-200205000-00003 PMID 12010689.

2. Harris P, Snell L, Talbot M, Harden RM. Competency-based medical education: implications for undergraduate programs. Med Teach. 2010;8: 646-50. https://doi.org/10.3109/0142159X.2010.500703 PMID 20662575.

3. Hawkins RE, Welcher CM, Holmboe ES, Kirk LM, Norcini JJ, Simons KB, et al. Implementation of competency-based medical education: are we addressing the concerns and challenges? Med Educ. 2015;11:1086-102. https://doi.org/10.1111/medu.12831 PMID 26494062.

4. Frank JR, Danoff D. The CanMEDS initiative: implementing an outcomesbased framework of physician competencies. Med Teach. 2007;7:642-7. https://doi.org/10.1080/01421590701746983 PMID 18236250.

5. Simpson JG, Furnace J, Crosby J, Cumming AD, Evans PA, Friedman Ben David M, et al. The Scottish doctor--learning outcomes for the medical undergraduate in Scotland: a foundation for competent and reflective practitioners. Med Teach. 2002;2:136-43. https://doi.org/10.1080/0142159022 0120713 PMID 12098432

6. Norman G, Norcini J, Bordage G. Competency-based education: milestones or millstones? J Grad Med Educ. 2014;1:1-6. https://doi.org/10.4300/JGMED-13-00445.1 PMID 24701301.

7. Frank JR, Snell LS, Cate OT, Holmboe ES, Carraccio C, Swing SR, et al. Competency-based medical education: theory to practice. Med Teach. 2010; 8:638-45. https://doi.org/10.3109/0142159X.2010.501190 PMID 20662574.

8. Skilbeck M. School-Based Curriculum Development. In: Lieberman A, editor. The Roots of Educational Change. Dordrecht: Springer; 2005. p. 109-32. https://doi.org/10.1007/1-4020-4451-8_7.

9. Van der Vleuten CPM. The assessment of professional competence: developments, research and practical implications. Adv Health Sci Educ. 1996;1:41-67. https://doi.org/10.1007/BF00596229 PMID 24178994. 
10. Van der Vleuten CPM, Schuwirth LWT. Assessing professional competence: from methods to programmes. Med Educ. 2005;3:309-17.

11. van der Vleuten CP, Schuwirth LW, Driessen EW, Govaerts MJ, Heeneman S. 12 tips for programmatic assessment. Med Teach. 2014;20:1-6. https://doi. org/10.1111/j.1365-2929.2005.02094.x PMID 15733167.

12. Westerhaus M, Finnegan A, Haidar M, Kleinman A, Mukherjee J, Farmer P. The necessity of social medicine in medical education. Acad Med. 2015; 90(5):565-8. https://doi.org/10.1097/ACM.0000000000000571.

13. Rasanathan K, Montesinos EV, Matheson D, Etienne C, Evans T. Primary health care and the social determinants of health: essential and complementary approaches for reducing inequities in health. J Epidemiol Community Health. 2011;8:656-60. https://doi.org/10.1136/jech.2009.093914 PMID 19933684.

14. Association of American Medical Colleges. Behavioral and Social Science Foundations for Future Physicians. Washington, DC: Association of American Medical Colleges; 2011. https://www.aamc.org/download/271020/data/beha vioralandsocialsciencefoundationsforfuturephysicians.pdf. Updated August 19, 2109. Assessed November 24

15. Cantey DS, Randolph SD, Molloy MA, Carter B, Cary MP. Student-developed simulations: enhancing cultural awareness and understanding social determinants of health. J Nurs Educ. 2017;4:243-6. https://doi.org/10.3928/ 01484834-20170323-11 PMID 28383751.

16. Leinster S. Evaluation and assessment of social accountability in medical schools. Med Teach. 2011;8:673-6. https://doi.org/10.3109/0142159X.2011. 590253 PMID 21774656.

17. Sharma M, Pinto AD, Kumagai AK. Teaching the social determinants of health: a path to equity or a road to nowhere? Acad Med. 2018;1:25-30. https://doi.org/10.1097/ACM.0000000000001689 PMID 28445214.

18. Kim K, Lee YM. Understanding uncertainty in medicine: concepts and implications in medical education. Korean J Med Educ. 2018:3:181-8. https://doi.org/10.3946/kjme.2018.92 PMID 30180505.

19. Fox RC. Medical Uncertainty Revisited. Chapter 26. In: Handbook of social studies in health and medicine: SAGE Publications Ltd; 2000. p. 409-25. https://doi.org/10.4135/9781848608412.n26.

20. Rajesh PK, Bharathi S. The Kurusowa approach to teaching learning. Asia Pacific Scholar. 2017;3:28. https://doi.org/10.29060/TAPS.2017-2-3/LE1045.

21. Phillips DC. Interpreting the seventies, or, Rashomon meets educational theory. Educ Theory. 2000;3:321-38.

22. Cotler MP. Bioethics consultation: the Rashomon effect. Med Law. 2013; 32(2):205-12

23. Hafferty FW, Franks R. The hidden curriculum, ethics teaching, and the structure of medical education. Acad Med. 1994;11:861-71. https://doi.org/1 0.1097/00001888-199411000-00001 PMID 7945681.

24. Atkin JM. A new evaluator perspective for professors of education. In: Bagley A, editor. The professor of education: an assessment of conditions. Minneapolis: Society of Professors of education, College of Education, University of Minnesota; 1975. Retrieved from https:// societyofprofessorsofeducation.files.wordpress.com/2013/07/profed_atkins. pdf. Accessed November 25, 2019.

25. Atkin JM, Black PJ, Coffey JE, Assessment in the classroom. Classroom Assessment and the National Science Education Standards. In: National Research Council. Washington DC: National Acedemiy Press; 2001. p. 23-58.

26. Ministry of Education. Karikyuramukaihatsu no kadai. Tokyo: Ministry of Finance Press; 1975. p. 49-55. (Japanese)

27. Nakayama K. A Fundamental Consideration on the Curriculum Development in Medical Schools. Med Educ. 1981;12:40-4. https://doi.org/1 0.11307/mededjapan1970.12.40 (Japanese).

28. Tanaka J. Rashomon approach as educational method. Asia Pacific Scholar 2018;2:54. https://doi.org/10.29060/TAPS.2018-3-2/LE2032

29. Model Core Curriculum for Medical Education in Japan. http://www.mext. go.jp/component/a_menu/education/detail/_icsFiles/afieldfile/2018/06/1 8/1325989_30.pdf. Updated in 2016. Accessed 9 August 2018.

30. Cleary M, Happell B, Lau ST, Mackey S. Student feedback on teaching: some issues for consideration for nurse educators. Int J Nurs Pract. 2013;19(Suppl 1):62-6. https://doi.org/10.1111/ijn.12018 PMID 23425381.

31. Goldfarb S, Morrison G. Continuous curricular feedback: a formative evaluation approach to curricular improvement. Acad Med. 2014;2:264-9. https://doi.org/10.1097/ACM.0000000000000103 PMID 24362392.

32. Braun V, Clarke V. Using thematic analysis in psychology. Qual Res Psychol. 2006;2:77-101. https://doi.org/10.1191/1478088706qp063oa.
33. Sinnott C, Bradley CP. Multimorbidity or polypharmacy: two sides of the same coin? J Comorb. 2015;5:29-31. https://doi.org/10.15256/joc.2015.5.51 PMID 29090158

34. Agarwal AK, Murinson BB. New dimensions in patient-physician interaction: values, autonomy, and medical information in the patient-centered clinical encounter. Rambam Maimonides Med J. 2012;3:e0017. https://doi.org/10. 5041/RMMJ.10085 PMID 23908841.

35. Redfern N. Film style and narration in Rashomon. J Japanese Korean Cinema. 2013;1-2:21-36. https://doi.org/10.1080/17564905.2013.10820070.

36. Persico D, Pozzi F, Anastopoulou S, Conole G, Craft B, Dimitriadis Y, et al. Learning design Rashomon I - supporting the design of one lesson through different approaches. Research in Learning Technology. Special Suppl Art Sci Learn Design. 2013;21:20224. https://doi.org/10.3402/rlt.v21i3.20224.

37. Prieto LP, Dimitriadis $Y$, Craft B, Michael D, Emin V, Katsamani M, et al. Learning design Rashomon II - exploring one lesson through multiple tools. Res Learn Technol. 2013;21:20057. https://doi.org/10.3402/rlt.v21i3.20057.

38. Eva KW, Hodges BD. Scylla or Charybdis? Can we navigate between objectification and judgement in assessment? Med Educ. 2012;9:914-9. https://doi.org/10.1111/j.1365-2923.2012.04310.x PMID 22891912.

39. Eva KW. Dialogue in medical education: enabling the academic voyeur that lurks inside us all. Med Educ. 2012;9:826-7. https://doi.org/10.1111/j.1365-2 923.2012.04326.x PMID 22891901.

40. Bohm D, factor D, Garrett P. dialogue-a proposal. http://www.david-bohm. net/dialogue/dialogue_proposal.html. Updated December 31, 2018. Accessed 9 August 2018.

41. Roth WD, Mehta JD. The Rashomon effect combining positivist and Interpretivist approaches in the analysis of contested events. Sociol Methods Res. 2002;2:131-73. https://doi.org/10.1177/004912402237292.

42. Sweller J. Cognitive load during problem solving: effects on learning. Cogn Sci. 1988;2:257-85. https://doi.org/10.1207/s15516709cog1202_4.

43. Lave J, Wenger E. Situated learning: legitimate peripheral participation. Cambridge: Cambridge University Press; 1991.

44. Whitman N. A review of constructivism: understanding and using a relatively new theory. Fam Med. 1993;8:517-21 PMID 8405799.

\section{Publisher's Note}

Springer Nature remains neutral with regard to jurisdictional claims in published maps and institutional affiliations.

Ready to submit your research? Choose BMC and benefit from:

- fast, convenient online submission

- thorough peer review by experienced researchers in your field

- rapid publication on acceptance

- support for research data, including large and complex data types

- gold Open Access which fosters wider collaboration and increased citations

- maximum visibility for your research: over $100 \mathrm{M}$ website views per year

At $\mathrm{BMC}$, research is always in progress.

Learn more biomedcentral.com/submissions 